\title{
ПОГЛЯД НА ТРИВАЛУ АНТИГІПЕРТЕНЗИВНУ ТЕРАПІЮ У ХВОРИХ НА ЦУКРОВИЙ ДІАБЕТ
}

\author{
๑О. В. Давидович, Н. Я. Давидович, В. О. Лихацька, Т. Р. Волощук, \\ А. Д. Попов, І. В. Чепой \\ Національна медична академія післядипломної освіти імені П. Л. Шупика \\ ДВНЗ «Тернопільський державний медичний університетімені І. Я. Горбачевського МОЗ України»
}

РЕЗЮМЕ. Призначення інгібіторів АПФ, метаболічно нейтрального діуретика індапаміду та агоністів І1-імідазолінових рецепторів хворим з АГ та ЦД дозволяє забезпечити зниження загально та серцево-судинно смертності.

Вступ. Лікування артеріально гіпертензі залишається одним з основних напрямків комплексно терапі хворих на цукровий діабет II типу (ЦД). Антигіпертензивна терапія у цих пацієнтів дозволяє запобігти ряду ускладнень, покращити якість життя та продовжити його тривалість.

Основна частина. Артеріальна гіпертензія часто спостерігається у хворих на ЦД ІІ типу. Підвищення АТ зустрічається в 2 рази частіше у пацієнтів $з$ діабетом, порівняно з особами аналогічного віку, що не мають цього захворювання.

В останні роки активно дискутується питання щодо цільових значень артеріального тиску у хворих на цукровий діабет. До недавнього часу всі рекомендаці зводились до того, що, враховуючи більш високий серцево-судинний ризик, корекція артеріального тиску в цій групі обстежених повинна бути більш агресивною та досягати показників менше 130/80 мм рт. ст. Але при обстеженні більш ніж шести тисяч хворих з АГ та цукровим діабетом (дослідження ACCORD) не було виявлено будь-яко різниці у ризику розвитку інфаркту міокарда, інсультів та загально кардіоваскулярно смертності у хворих з показниками систолічного артеріального тиску нижче за 130 мм рт. ст. та 130140 мм рт. ст. Ці дані обумовили необхідність перегляду підходів до показників цільового артеріального тиску у хворих на цукровий діабет в бік менш жорстких значень. Так, в 2013 р. в сумісних рекомендаціях Європейсько асоціаці 3 артеріально гіпертензі та Європейсько кардіологічно асоціаці рекомендується досягнення цільового артеріального тиску у хворих на цукровий діабет нижче 140/ 85 мм рт. ст. (Mancialetal., 2013). У протоколі лікування хворих з цукровим діабетом II типу, затвердженому Міністерством охорони здоров'я Укра ни, рекомендовано підтримувати показники артері- ального тиску у таких пацієнтів на рівні, нижчому за 140/80 мм рт. ст. Достовірно відомо, що інгібітори АПФ при ЩД роблять значний внесок в зниження ступеня ураження органів-мішеней: зменшується рівень проте нурі, покращується мікроциркуляція в серці та мозку. В дослідженні ADVANCE було переконливо показано, що активна гіпотензивна терапія шляхом призначення інгібітора АПФ периндоприлу I та метаболічно нейтрального діуретика індапаміду (Наліпрел-бі-форте)є ефективною. Ефективними також $є$ поєднання раміприлу з діуретикам (Амприл Н, Амприл НH, етап $\mathrm{H}$, етап $\mathrm{HL}$ ), вони знижують загальну смертність на $14 \%$, а кардіоваскулярну на $18 \%$ протягом 10 років спостереження.

В останні роки в лікуванні хворих з АГ та цукровим діабетом стали використовувати препарати з центральним механізмом ді - агоністи I1-імідазолінових рецепторів. Доведено, що моксонідин знижує активність симпатичного відділу нервово системи шляхом стимуляці I1-імідазолінових рецепторів в судиноруховому центрі довгастого мозку. В Укра ні препарат існує під торговими назвами «Фізіотенс» та «Моксогама». Під впливом моксонідину систолічний АТ знижується на 2030 мм рт. ст., а діастолічний - на 10-20 мм рт. ст. Гіпотензивний ефект проявляється вже через 30 хв та триває до 24 годин. Єдиний шлях виведення - нирковий. Препарат сприятливо впливає на обмін ліпідів та вуглеводів, сприяе зворотному розвитку гіпертрофі лівого шлуночка.

Висновки. Призначення інгібіторів АПФ, метаболічно нейтрального діуретика індапаміду та агоністів I1-імідазолінових рецепторів хворим з АГ та ЏД дозволяє забезпечити зниження загально та серцево-судинно смертності. 